\title{
Pasikula (Pasta Kunyit Untuk Axilla) Sebagai Perontok Herbal Bulu Ketiak
}

\author{
Wawan Kurniawan, Novi Nurul Awaliyah, Wida Silfia, Ijang Ikbal Nawawi, Restu Febriyanto dan Leni Sri Mulyani \\ Institut Pendidikan Indonesia \\ Jl. Terusan Pahlawan No.32, Sukagalih, Kec. Tarogong Kidul, Kabupaten Garut \\ wawankurniawan.bio@gmail.com
}

\begin{abstract}
The aim of this study was to develop business by exploiting the potential of turmeric (Curcuma longa Linn.) into hair removal product. The abundance production of turmeric in Garut district is contrary with the lack of public awareness in utilizing it. On the other hand, society need herbal cosmetic products made from natural and not harmfull substances to health, including hair removal product. Curcumin and its analogous compounds contained in turmeric have been reported to have biological effects as antiandrogenic, so it has the potential to help inhibit unwanted hair growth on the body for example in the armpit area. Turmeric is processed into economic value products by forming it into turmeric paste hair removal herbal product. A wide of hair removal products can be found in the market. However hair removal herbal product made from turmeric still rarely found. It is an opportunity to establish business of hair removal herbal product from turmeric. The product is named PASIKULA which is packed in a small bottle containing 50 capsules of turmeric paste powder, the price of PASIKULA is IDR 8.000,-. It makes the product affordable by all levels of society. Promotion and marketing are done actively through online and offline media. The average sales which are increasing every month is an evidence that PASIKULA can be accepted by the society. PASIKULA has potential business opportunities that it is able to increase the economic value of turmeric.
\end{abstract}

Keywords- Turmeric; Pasikula; Hair Removal.

\begin{abstract}
Abstrak - Tujuan dari penelitian ini adalah untuk mengembangkan usaha dengan memanfaatkan potensi kunyit menjadi produk perontok bulu herbal. Produksi kunyit yang melimpah di Kabupaten Garut bertolak belakang dengan minimnya kesadaran masyarakat dalam pemanfaatannya. Disisi lain masyarakat membutuhkan produk kosmetik herbal berbahan alami dan tidak berbahaya bagi kesehatan, termasuk produk perontok bulu. Kandungan senyawa Kurkumin dan senyawa analognya pada kunyit telah dilaporkan memiliki efek biologis sebagai antiandrogenik sehingga berpotensi dalam membantu menghambat pertumbuhan rambut di bagian tubuh yang tidak inginkan seperti di area ketiak. Kunyit diolah menjadi suatu produk bernilai jual dengan membentuknya menjadi pasta kunyit sebagai produk perontok bulu herbal. Beberapa produk perontok bulu dapat ditemui dipasar. Namun perontok bulu herbal berbahan baku kunyit belum ada di pasar. Hal tersebut menjadi peluang untuk mendirikan usaha perontok bulu herbal dari kunyit. Produk ini bernama PASIKULA dikemas dalam botol kecil berisi 50 kapsul serbuk pasta kunyit dan dijual dengan harga Rp. 8.000,- yang terjangkau oleh semua kalangan masyarakat. Promosi dan pemasaran dilakukan secara aktif melalui media online dan offline. Rata-rata penjualan yang meningkat setiap bulannya merupakan bukti bahwa PASIKULA dapat diterima oleh masyarakat. PASIKULA ini memiliki peluang usaha yang cukup potensial yang mampu meningkatkan nilai ekonomis kunyit.
\end{abstract}

Kata Kunci- Kunyit; Pasikula; Perontok Bulu.

\section{PENDAHULUAN}

Kunyit merupakan tanaman rempah potensial yang banyak dibudidayakan oleh masyarakat luas. Kabupaten Garut menjadi salah satu sentra penghasil kunyit di Jawa Barat. Berdasarkan data ATAP 2011 produksi kunyit di Kabupaten Garut mencapai 0,94 ribu ton dengan kontribusi sebesar 9,91\% terhadap total produksi kunyit di Jawa Barat [1]. Kunyit yang dihasilkan masih sangat minim pemanfaatannya hanya sebatas bahan bumbu dapur atau jamu, belum dikembangkan menjadi suatu produk bernilai jual dan baru menjadi komoditas perdagangan bahan baku. Kesadaran masyarakat yang rendah akan potensi yang dimiliki bertolak belakang dengan sumber daya alam yang melimpah. Oleh karena itu, perlu dilakukan pemanfaatan dan pengembangan lebih lanjut untuk meningkatkan nilai jual kunyit. Salah satu upaya inovasi kreatif yang dapat dilakukan yaitu dengan cara mengolah kunyit menjadi produk perontok bulu herbal.

Menghilangkan bulu atau rambut halus yang tumbuh diarea tubuh tertentu menjadi trend yang semakin berkembang di masyarakat saat ini. Rambut ketiak mempunyai fungsi tersendiri, namun bagi sebagian orang dianggap sebagai bagian tubuh yang tidak diinginkan karena sedikit mengganggu penampilan dan mengurangi rasa percaya diri. Adapun alasan lainnya membersihkan rambut ketiak secara rutin merupakan salah satu cara dalam menjaga kebersihan dan kesehatan serta dapat mengurangi bau badan [2]. Pandangan ini kemudian berkembang dan meluas seiring trend produk perontok bulu dipasaran.

Beberapa produk perontok bulu sudah banyak ditemui di pasar, akan tetapi masih jarang ditemukan produk perontok bulu yang terbuat dari bahan alami dan tidak berbahaya bagi kesehatan. Adanya 
kecenderungan pola hidup sehat untuk kembali ke alam (back to nature) menyebabkan masyarakat mulai beralih menggunakan bahan alami untuk meminimalisir efek samping seperti obat-obatan kimia [3].

PASIKULA (Pasta Kunyit Untuk Axilla) merupakan usaha yang cukup potensial, hal ini dikarenakan masyarakat masa kini membutuhkan produk perontok bulu yang aman dan sehat untuk digunakan dalam jangka waktu yang panjang sehingga peluang untuk mendapatkan pangsa pasar terbuka lebar. Selain itu bahan utama yang berasal dari kunyit merupakan salah satu bentuk pemanfaatan serta sebagai solusi untuk meningkatkan nilai ekonomis kunyit.

\section{KAJIAN PUSTAKA}

Kunyit merupakan tanaman dari golongan Zingiberaceae berupa semak dan sifat tahunan (perennial) yang tersebar di seluruh daerah tropis [4]. Kandungan senyawa kimia dalam kunyit yaitu kurkumin, demetoksikurkumin, bisdemetoksikurkumin, minyak atsiri, gula, protein, dan resin [5]. Senyawa aktif utama dalam rimpang kunyit yang mempunyai keaktifan fisiologi adalah kurkumin atau kurkuminoid [6]. Kurkumin dan senyawa analognya memiliki kemampuan sebagai antioksidan, anti-HIV, anti mutagenik, anti angiogenik, anti malaria, anti tuberkuler, anti androgenik, dan menghambat aktivitas COX [7].

Manfaat utama tanaman kunyit antara lain sebagai bahan obat tradisional, bahan baku industri jamu dan kosmetik dan bahan baku bumbu masak. Kunyit dimasukan dalam daftar prioritas World Health Organization (WHO) sebagai tanaman obat yang paling banyak dipakai diberbagai negara dan sering disebut dalam buku-buku farmasi serta ditulis dalam resep tradisional maupun resep resmi [8]. Kunyit juga merupakan bahan alami yang digunakan dalam resep pembuatan kosmetik tradisional seperti lulur. Penggunaan lulur kunyit dapat menghilangkan rambut halus pada kulit [9].

Rambut merupakan helaian seperti benang tipis yang tumbuh hampir diseluruh permukaan kulit, kecuali telapak tangan dan telapak kaki. Fungsi rambut antara lain untuk meningkatkan kepekaan kulit terhadap rangsangan sentuhan. Rambut dibagi menjadi 3 macam yaitu rambut lanugo, bulu roma (vellus), dan rambut terminal. Rambut lanugo atau disebut juga dengan rambut janin yaitu rambut khusus bayi dalam kandungan, mulai tumbuh dipermukaan kulit bayi. Bulu roma atau vellus memiliki ciri pendek, tipis, halus dan hampir tidak berwarna. Selain itu tertanam secara dangkal didalam dermis, dan tidak memiliki sumsum (medulla). Sedangkan rambut terminal memiliki ciri tebal, panjang, warnanya lebih gelap atau pigmen jelas, tertanam jauh didalam dermis [10].

Rambut mempunyai akar rambut yang disebut juga folikel rambut. Folikel rambut mempunyai dasar yang besar, disebut umbi rambut. Umbi rambut tersusun atas papil rambut (yang mengandung jaringan ikat, pembuluh darah dan saraf) dan matrik rambut. Papil rambut inilah yang memberikan nutrisi pada perumbuhan rambut [9]. Pertumbuhan rambut yang berlebih dipengaruhi oleh hormon androgen. Beberapa hormon androgen tersebut antara lain 5adihydrotestosteron (DHT), adrostenedione (A), dihydroepiandosterone (DHEA) dan dihydroepiandosterone-sulfat (DHEA-S) [11].

Androgen merupakan hormon-hormon steroid penting yang menentukan ekspresi fenotip pria, seperti perkembangan karakteristk sekunder hingga inisiasi dan menjaga spermatogenesis. Androgen disintesis dan disekresikan kedalam aliran darah dan sebagian besarnya membentuk testosteron. Pada pria testosteron disintesis di dalam testis sedangkan pada wanita testosteron disintesis secara langsung. Secara irreversible, testosteron dikonversi menjadi dihydrotestosteron (DHT) oleh NADP. (DHT) merupakan androgen alami yang paling potent yang terdapat pada manusia. Androgen memasuki sel target (folikel) lalu berikatan secara langsung dengan reseptor androgen atau setelah dikonversi menjadi DHT oleh 5a-reduktase [12]. Setelah hormon androgen terikat pada reseptor folikel rambut pertumbuhan rambut mulai dikontrol [11].

Perubahan rambut vellus menjadi rambut terminal yang menyebabkan rambut berlebih pada tubuh tidak lepas dari kerja androgen di folikel rambut dan suatu enzim yang dikenal dengan $5 \mathrm{a}$ reduktase, enzim ini mengkonversi testosteron menjadi bentuk 5-a-dihydrotestosteron atau DHT. Dihydrotestosterone memiliki afinitas tinggi untuk berikatan pada suatu reseptor spesifik yang dikenal dengan reseptor androgen pada folikel rambut, dengan demikian pertumbuhan rambut yang berlebih 
dapat diterapi secara farmakologis dengan penghambat dari kerja androgen pada folikel rambut [11]. Kerja androgen pada folikel rambut dapat dihambat olah senyawa antiandrogenik dengan cara menghambat enzim 5-a-Reduktase yang berperan dalam mengkonversi testosteron menjadi dihydrotestosteron (DHT) [13].

Kunyit mengandung senyawa aktif kurkumin. Senyawa tersebut telah diteliti memiliki efek biologis sebagai antiandrogenik yang berperan dalam menghambat pengikatan DHT pada reseptor androgen di folikel rambut, sehingga mengurangi aliran darah kefolikel rambut. Efek potensial tersebut menjadi landasan sebagai terapi memperlambat pertumbuhan rambut, akibatnya rambut yang tumbuh akan menjadi semakin tipis dan tidak didukung dengan adanya pertumbuhan rambut.

\section{METODE PENELITIAN}

Metode pelaksanaan pembuatan pasta kunyit untuk axilla (PASIKULA) meliputi beberapa tahapan diantaranya tahap Pra-produksi, Produksi dan Pemasaran.

1. Pra-produksi

Tahap-tahap yang dilakukan pada pra-produksi PASIKULA adalah sebagai berikut:

1) Persiapan

Pada tahap ini dilakukan persiapan dalam pemilihan dan penyediaan tempat, sarana dan prasarana lain untuk menunjang proses produksi, serta menyusun rencana pelaksanaan.

2) Penyediaan alat dan bahan

Pada tahap ini dilakukan pengumpulan alat dan bahan yang diperlukan dalam proses produksi.

3) Pembuatan sampel produk

Pembuatan produk sampel merupakan langkah awal untuk mengetahui kualitas produk sebelum dipasarkan dalam jumlah besar.

4) Pengujian produk

Pengujian produk dilakukan dengan menguji sampel produk meliputi sifat mutu fisik, efektivitas, keamanan dan aseptabilitas. Sifat mutu fisik meliputi pemeriksaan organoleptis, pemeriksaan homogenitas, uji $\mathrm{pH}$ dan uji daya sebar. Uji efektivitas meliputi pengujian waktu kering dan kemudahan dibersihkan, uji keamanan merupakan pengujian terhadap iritasi sedangkan uji aseptabilitas merupakan pemeriksaan terhadap kesukaan.

2. Produksi

Tahap-tahap yang dilakukan pada proses produksi PASIKULA adalah sebagai berikut:

1) Rimpang kunyit yang telah disortir dicuci sampai bersih.

2) Rimpang kunyit yang telah dicuci kemudian dipotong-potong menjadi ukuran lebih kecil untuk memperbesar luas permukaan, sehingga mempercepat proses penguapan ketika dijemur.

3) Jemur potongan-potongan kunyit di bawah sinar matahari, dan dilanjutkan dengan pengeringan didalam oven selama 30 menit pada suhu $50^{\circ} \mathrm{C}$.

4) Giling kunyit yang telah dikeringkan menggunakan blender.

5) Kemudian saring menggunakan ayakan untuk mendapatkan serbuk kunyit halus.

6) Tambahkan 1,2 Liter air mawar pada 2 kilogram serbuk kunyit halus, kemudian aduk secara merata sampai membentuk pasta.

7) Kemudian pasta kunyit dikeringkan di dalam oven selama 10 menit pada suhu $50^{\circ} \mathrm{C}$.

8) Haluskan pasta kunyit yang telah dikeringkan dan saring kembali menggunakan ayakan.

9) Tambahkan 1,2 kilogram susu bubuk kedalam serbuk pasta kunyit dan aduk secara merata.

10) Kemudian serbuk pasta kunyit dimasukan ke dalam kapsul 0,5 gram.

11) Kapsul dikemas dalam kemasan botol kecil sebanyak 50 kapsul.

3. Pemasaran

Pemasaran yang telah dilakukan dari awal produksi sampai akhir produksi yaitu:

1) Menjual produk langsung secara person to person kepada konsumen di dalam maupun luar lingkungan kampus.

2) Menjual produk secara online melalui media sosial.

3) Aktif mengikuti pameran dan gelar produk di berbagai event kampus.

4) Promosi dan penawaran melaui teman atau relasi, semakin banyak relasi produk semakin dikenal di kalangan masyrakat.

5) Menyebar brosur yang didesain secara menarik, yang di dalamnya mencakup informasi mengenai gambaran produ, bonus, harga dan cara pemesanan.

6) Menjual produk dengan harga yang terjangkau oleh masyarakat.

7) Menyediakan waktu untuk promo diskon khusus. 
8) Potongan harga tertentu untuk distributor maupun pembelian skala besar.

\section{HASIL DAN PEMBAHASAN}

Pada tahap pra-produksi dilakukan tahap pembuatan dan pengujian produk sampel yang bertujuan untuk evaluasi dan perbaikan produk sebelum dipasarkan dalam jumlah besar. Hasil pengujian terhadap produk PASIKULA menunjukan beberapa hal seperti dilihat pada tabel 4.1

Tabel 4.1 Uji Pemeriksaan Pasta Kunyit

\begin{tabular}{|c|c|c|}
\hline No. & Uji Pemeriksaan & Hasil \\
\hline \multirow[t]{8}{*}{1} & Sifat Mutu Fisik & \\
\hline & - Organoleptis (bau, & Menimbulkan bau khas \\
\hline & bentuk, dan warna) & kunyit, berbentuk serbuk \\
\hline & & $\begin{array}{l}\text { dan berwarna kuning } \\
\text { kecoklatan }\end{array}$ \\
\hline & Homogenitas & Terlihat bintik-bintik \\
\hline & & $\begin{array}{l}\text { partikel pada permukaan } \\
\text { pasta }\end{array}$ \\
\hline & $\mathrm{pH}$ & 7 \\
\hline & Daya sebar & Rendah \\
\hline \multirow[t]{3}{*}{2} & Efektivitas & \\
\hline & - Waktu kering & $10-15$ menit \\
\hline & $\begin{array}{l}\text { Kemudahan } \\
\text { dibersihkan }\end{array}$ & $\begin{array}{l}\text { Mudah tapi menyisakan } \\
\text { bekas warna kuning di } \\
\text { kulit }\end{array}$ \\
\hline 3 & Keamanan (iritasi) & $\begin{array}{l}\text { Tidak menimbulkan efek } \\
\text { gatal dan kemerahan pada } \\
\text { kulit }\end{array}$ \\
\hline 4 & Aseptabilitas (kesukaan) & $\begin{array}{l}\text { Mudah untuk } \\
\text { diaplikasikan dan tidak } \\
\text { menimbulkan efek } \\
\text { samping }\end{array}$ \\
\hline
\end{tabular}

Program Kreativitas Mahasiswa Bidang Kewirausahaan dengan produk PASIKULA (Pasta Kunyit Untuk Axilla) ini telah diterima oleh masyarakat, hal ini terbukti dengan jumlah pemesan yang cukup banyak. Hasil penjualan PASIKULA selama 3 bulan proses pemasaran dapat dilihat pada tabel 4.2 .

Tabel 4.2 Realisasi Penjualan PASIKULA

\begin{tabular}{llll}
\hline $\begin{array}{l}\text { Penjualan } \\
\text { (item) }\end{array}$ & $\begin{array}{l}\text { Harga } \\
\text { pokok } \\
\text { per item } \\
(\mathbf{R p})\end{array}$ & $\begin{array}{l}\text { Pendapatan } \\
(\mathbf{R p})\end{array}$ & $\begin{array}{l}\text { Keuntungan } \\
(\mathbf{R p})\end{array}$ \\
\hline \multirow{3}{*}{ Bulan April } \\
\hline 38 & 5.840,- & $304.000,-$ & $82.080,-$ \\
& Sub total & $304.000,-$ & $82.080,-$ \\
\hline \multicolumn{5}{c}{ Bulan Mei } \\
\hline
\end{tabular}

\begin{tabular}{llrl}
\hline 42 & $5.840,-$ & $336.000,-$ & $90.720,-$ \\
& Sub total & $336.000,-$ & $90.720,-$ \\
\hline \multicolumn{3}{c}{ Bulan Juni } \\
\hline 63 & $5.840,-$ & $504.000,-$ & $136.080,-$ \\
& Sub total & $504.000,-$ & $136.080,-$ \\
\hline & Total & $1.144 .000,-$ & $308.880,-$ \\
\hline
\end{tabular}

Total produk yang telah terjual per bulan Juli 2019 adalah sebanyak 143 item. Dengan rincian, pada produksi tahap kesatu bulan April 2019 telah terjual sebanyak 38 item. Kemudian dilakukan produksi tahap kedua pada bulan Mei 2019. Pada tahap kedua ini telah terjual sebanyak 42 item. Kemudian memproduksi pada tahap ketiga pada bulan Juni 2019. Pada produksi ketiga ini mampu terjual sebanyak 63 item produk. Dari 143 item produk yang telah terjual, total pendapatan yang diperoleh sebesar Rp. 1.114.000,- dengan keuntungan Rp. 308.880,-.

Dari berbagai kegiatan yang telah direncanakan mulai dari pra-produksi, produksi dan pemasaran. Berikut merupakan rincian kegiatan yang sudah terlaksana maupun belum terlaksana yang ditunjukan pada tabel 4.3.

Tabel 4.3 Ketercapaian Target Luaran

\begin{tabular}{clcc}
\hline \multirow{2}{*}{ No } & \multicolumn{1}{c}{ Target } & \multicolumn{2}{c}{ Ketercapaian Target (100\%) } \\
\cline { 3 - 4 } & & Terlaksana & $\begin{array}{c}\text { Belum } \\
\text { Terlaksana }\end{array}$ \\
\hline 1 & $\begin{array}{l}\text { Survey lokasi bahan } \\
\text { baku }\end{array}$ & $100 \%$ & - \\
\hline 2 & $\begin{array}{l}\text { Pemenuhan alat dan } \\
\text { bahan }\end{array}$ & $85 \%$ & $15 \%$ \\
\hline 3 & Tempat produksi & $100 \%$ & - \\
\hline 4 & Pelaksanaan produksi & $85 \%$ & $15 \%$ \\
\hline 5 & $\begin{array}{l}\text { Promosi dan } \\
\text { pemasaran }\end{array}$ & $75 \%$ & $25 \%$ \\
\hline 6 & Seminar & $80 \%$ & $20 \%$ \\
\hline 7 & Evaluasi & $75 \%$ & $25 \%$ \\
\hline 8 & Laporan akhir & $100 \%$ & - \\
\hline 9 & Artikel ilmiah & $100 \%$ & - \\
\hline & Tingkat pencapaian & $88,88 \%$ & $11,12 \%$ \\
\hline & & & \\
\hline
\end{tabular}

PASIKULA (Pasta Kunyit Untuk Axilla) memiliki potensi pengembangan usaha yang lebih luas. Adapun untuk rencana keberlanjutan program, kami berencana memproduksi dan menjual produk PASIKULA ini dalam skala besar melalui beberapa program yaitu: 
1. Bekerja sama dengan outlet-outlet kecantikan seKabupaten Garut sebagai tempat pemasaran produk kami.

2. Pendaftaran hak paten dan merek dagang.

3. Pendaftaran produk ke BPOM.

4. Membuat rumah produksi (CV).

Rencana peningkatan kapasitas produksi juga akan dilakukan, yaitu dengan melakukan pengadaan mesin yang lebih canggih untuk proses pengolahan sampai pengemasan, sehingga bisa didapatkan produk yang banyak dalam waktu yang lebih singkat, lebih higienis, serta dapat meminimalisir risiko kesalahan dalam takaran komposisi bahan.

\section{KESIMPULAN DAN SARAN}

Produk PASIKULA merupakan produk hasil karya inovasi kreatif dengan memanfaatkan kunyit yang pada umumnya masih minim pemanfaatannya oleh masyarakat serta sebagai solusi untuk meningkatkan nilai ekonomi kunyit. Kandungan senyawa kurkumin dan senyawa analognya pada kunyit telah dilaporkan memiliki efek biologis sebagai antiandrogenik sehingga berpotensi dalam membantu menghambat pertumbuhan rambut diarea tubuh yang tidak diinginkan. Oleh karena itu, usaha ini sangat layak untuk dikembangkan karena kepedulian kami terhadap masyarakat untuk menggunakan produk berbahan alami, sekaligus mengajak masyarakat untuk mencintai produk tradisional.

PASIKULA dikemas dalam botol kecil berisi 50 kapsul serbuk pasta kunyit dengan harga Rp. 8.000,yang dirasa cukup terjangkau oleh masyarakat. Dengan adanya inovasi terbaru ini akan memudahkan masyarakat menemukan produk perontok bulu yang terbuat dari bahan alami, sehingga aman jika digunakan secara terus menerus bahkan dalam jangka waktu yang lama.

\section{UCAPAN TERIMA KASIH}

Segala puji bagi Allah, berkat rahmat dan atas ridho-Nya tim PKM-K PASIKULA mampu menyelesaikan artikel yang berjudul "PASIKULA (Pasta Kunyit Untuk Axilla) Sebagai Perontok Herbal Bulu Ketiak". Kami mengucapkan terima kasih kepada Kemenristekdikti yang telah mendanai Program Kreativitas Mahasiswa Bidang Kewirausahaan (PKM-K) tahun pendanaan 2019. Selain itu, kami juga mengucapkan terima kasih kepada lembaga Institut Pendidikan Indonesia, khususnya Program Studi Pendidikan Biologi, serta semua komponen yang ada di dalamnya yang telah banyak mendukung mulai dari tahap pengajuan proposal PKM-K, sampai sekarang. Terakhir, kami mengucapkan terima kasih kepada mitra yang mau bekerja sama dengan pihak Tim PKM-K PASIKULA.

\section{REFERENSI}

[1] Setjen Pertanian, "Info Ringkas Kunyit April 2013," 2013.

[2] A. Lanzalaco, K. Vanoosthuyze, C. Stark, D. Swaile, H. Rocchetta, and R. Spruell, "A comparative clinical study of different hair removal procedures and their impact on axillary odor reduction in men," J. Cosmet. Dermatol., pp. 58-65, 2016, doi:

10.1111/jocd.12197.

[3] Hernani, "Pengembangan Biofarmaka Sebagai Obat Herbal Untuk Kesehatan," Bul. Teknol.

Pasca Panen, vol. 7, no. 1, pp. 20-29, 2011.

[4] L. Labban, "Medicinal and pharmacological properties of Turmeric (Curcuma longa): A review," Int. J. Pharm. Biomed. Res., vol. 5, no. 1, pp. 17-23, 2014.

[5] J. S. Jurenka, "Anti-inflammatory properties of curcumin, a major constituent of Curcuma longa: A review of preclinical and clinical research," Altern. Med. Rev., vol. 14, no. 2, pp. 141-153, 2009.

[6] S. R. Anshori, S. I. Aisyah, and L. K. Darusman, "Induksi Mutasi Fisik dengan Iradiasi Sinar Gamma pada Kunyit (Curcuma domestica Val.)," J. Hortik. Indones., vol. 5, no. 3, pp. 84-94, 2014, doi:

10.29244/jhi.5.2.84-94.

[7] D. K. Agrawal and P. K. Mishra, "Curcumin and Its Analogues: Potential Anticancer Agents," Med. Res. Rev., vol. 30, no. 5, pp. 818-860, 2010, doi: 10.1002/med.20188.

[8] S. Y. Hartati, "Khasiat Kunyit Sebagai Obat Tradisional Dan Manfaat Lainnya," War. Penelit. Dan Pengemb. Tanam. Ind., vol. 19, no. 2, pp. 5-9, 2013.

[9] N. S. Silfi A and S. I. Widjajanti, Kosmetika Tradisional. Jakarta: LPP Press Universitas Negeri Jakarta, 2015.

[10] D. Ewamaharani and S. Dwiyanti, "Pengaruh Perbandingan Gula Dan Madu Terhadap Hasil Jadi Kosmetik Epilasi," e-journal, vol. 07, no. 2, pp. 36-43, 2018.

[11] U. Atmojo and D. M. Indramaya, "Patogenesis dan Penegakan Diagnosis Hirsutisme pada Bidang Dermatologi," Fkunair, vol. 22, no. 3, 
pp. 189-193, 2010.

[12] M. Akmal, "Androgen dihydrotestosterone dan perannya pada sistem reproduksi pria," Veterina Med., vol. 10, no. 1, pp. 119-130, 2017.
[13] J. Srivilai et al., "Curcuma aeruginosa Roxb. essential oil slows hair-growth and lightens skin in axillae; a randomised, double blinded trial," Phytomedicine, vol. 25, pp. 29-38, 2017, doi: 10.1016/j.phymed.2016.12.007. 